\title{
Erratum to: Litter Decomposition, and Associated Invertebrate Communities, in Wetland Ponds of the Copper River Delta, Alaska (USA)
}

\author{
Scott D. Tiegs • Sally A. Entrekin • Gordon H. Reeves • \\ Deyna Kuntzsch $\cdot$ Richard W. Merritt
}

Published online: 30 October 2013

(C) Society of Wetland Scientists 2013

\section{Erratum to: Wetlands}

DOI 10.1007/s13157-013-0470-5

The below Acknowledgements section was omitted from the original article.

Acknowledgements We are grateful for the contributions of many people who made this research possible. Mark Isken, School of Business, Oakland University, provided a valuable summary of the temperature data. Kevin Kuehn at the University of Southern Mississippi kindly performed the chemical analysis of each litter type. Emily Campbell at Michigan State University provided field assistance. Additional field and logistical support was provided by personnel at the Cordova Ranger District. Sean Mead at the Cordova Ranger District created Figure 1. Joshua Martin at Oakland University helped with processing the litter samples, and the litter-associated invertebrates. Daniel Sniegowski at the University of Central Arkansas identified macroinvertebrates.

The online version of the original article can be found at http://dx.doi.org/ 10.1007/s13157-013-0470-5.

S. D. Tiegs $(\bowtie)$

Department of Biological Sciences, Oakland University, Rochester, MI 48309, USA

e-mail: tiegs@oakland.edu

\section{S. A. Entrekin}

Department of Biology, University of Central Arkansas, Conway, AR 72035, USA

G. H. Reeves

USDA Forest Service, Pacific Northwest Research Station, Corvallis, OR 97331, USA

D. Kuntzsch

USDA Forest Service, Cordova Ranger District, Cordova, AK 99574, USA

R. W. Merritt

Department of Entomology, Michigan State University, East Lansing, MI 48824, USA 